\title{
ANALISIS PERBEDAAN KUALITAS RANDANG DAGING DENGAN MENGUNAKAN RESEP STANDAR DI KABUPATEN AGAM
}

\author{
Elida, Wirnelis Syarif, Yolanda Intan Sari \\ Pendidikan Kesejahteraan Keluarga, Fakultas Pariwisata dan Perhotelan, Universitas Negeri Padang, Jl. Prof. Dr. \\ Hamka, Air Tawar Bar,.Kec. Padang Utara, Kota Padang, Sumatera Barat 25171 \\ Email: 11111961@fpp.unp.ac.id
}

\begin{abstract}
Abstrak
Tujuan penelitian ini adalah untuk melihat perbedaan kualitas randang daging dengan mengunakan resep yang telah di standarkan di empat nagari yang ada di kabupaten Agam. Resep yang digunakan yaitu resep yang didapatkan di Nagari Sungai Tanang, Tabek Panjang, Baso dan Duo Koto. Jenis penelitian adalah metode campuran. Informan penelitian adalah Bundo Kanduang, dengan teknik pengumpulan data melalui observasi wawancara dan dokumentasi kemudian dilanjutkan dengan eksperimen. Hasil penelitian yaitu kualitas randang yang ada di empat nagari Kabupaten Agam memiliki perbedaan pada setiap kualitasnya yang dilihat dari aspek bentuk, warna, aroma, tekstur dan rasa.
\end{abstract}

Kata Kunci: Randang, Kabupaten Agam, Kualitas

\section{Abstract}

The purpose of this study was to see the differences in the quality of beef rendang using standardized recipes in four nagari in Agam district. The recipes used are recipes obtained in Nagari Sungai Tanang, Tabek Panjang, Baso and Duo Koto. This type of research is mixed methods. The research informant was Bundo Kanduang, with data collection techniques through observation, interviews and documentation, followed by experimentation. The result of the research is that the quality of rendang in the four nagari of Agam Regency has differences in each quality seen from aspects of shape, color, aroma, texture and taste.

Keywords: Randang, Agam Regency, Quality

Received: June 28, 2021 ; Accepted: July 8, 2021; Publish online: July 31, 2021

\section{Pendahuluan}

Makanan adat Minangkabau yang terkenal adalah randang. Pada tahun 2011 Cable News Networks (CNN) menetapkan Randang sebagai makanan terlezat di dunia. Randang adalah sebuah olahan masakan dengan cara dirandang yaitu dimasak dengan api kecil sambil diaduk-aduk sampai kering (Suri, 2012).

Randang merupakan makanan adat yang disebut juga sebagai Induak Jamba. Randang daging yang ada di daerah Sumatera Barat memiliki aroma dan rasa khas yang berbeda disetiap wilayahnya. Perbedaan ini disebabkan oleh penggunaan bumbu/rempah maupun teknik pengolahan. Sumatera Barat terdiri dari wilayah darek dan wilayah pasisia.

Salah satu Daerah darek (luhak) adalah Kabupaten Agam, hingga saat ini Kabupaten Agam merupakan daerah yang masih kental dengan upacara adat, daerah di Kabupaten Agam yang masih menjaga upacara adatnya adalah Nagari Sungai Tanang, Tabek Panjang, Baso dan Koto Baru. Pada setiap pelaksanaan acara adat selalu ada makanan adat salah satunya randang daging yang memiliki makna tersirat dan tujuannya tersendiri. "Makanan adat adalah makanan yang telah resmi atau telah ditentukan untuk disaijkan dalam acara atau peristiwa-peritiwa pelaksanaan upacara adat dalam suatu daerah" (Subarna dkk dalam Rini,2015). Randang yang ada di kabupaten agam memiliki perbedaan kualitas di setiap nagari tempat pengolahannya.

Penelitian awal yang telah peneliti lakukan telah didapatkannya resep standar dari Nagari Sungai Tanang, Tabek Panjang, Baso dan Koto Baru. Dari penilaian kualitas resep yang telah distandarkan memiliki hasil kualitas yang berbeda-beda. Dilihat dari masalah yang ada, maka diketahu bahwa kualitas randang yang diolah di nagari yang ada di kabupaten agam memiliki perbedaan sehingga sangat perlu dilakukan analisis perbedaan kualitas randang daging terhadap resep yang telah di standarkan. 


\section{Bahan dan Metode Penelitian}

Penelitian ini termasuk kedalam metode penelitian kuantitatif. Metode kuantitatif adalah suatu proses penelitian yang menggunakan data penelitian angka-angka yang diperoleh dari eksperimen. Jenis data yang digunakan yaitu data primer dan sekunder. Instrumen penelitian kuantitatif yaitu angket uji organoleptik kualitas bentuk, warna, aroma, tekstur dan rasa.

\section{Hasil dan Pembahasan}

Resep randang daging standar yang telah didapatkan pada penelitian sebelumnya dilanjutkan dengan penilaian uji organoleptik oleh panelis terbatas yaitu dosen Jurusan Tata Boga Universitas Negeri Padang untuk melihat perbedaan kualitas dari setiap resep yang didapatkan di beberapa Nagari yang ada di Kabupaten Agam meliputi kualitas bentuk, warna aroma, tekstur dan rasa.

Hasil penilaian organoleptik oleh 5 orang panelis terhadap kualitas randang daging dari resep standar Kabupaten Agam Nagari Sungai Tanang meliputi bentuk, warna, aroma, tekstur dan rasa dapat dilihat pada grafik berikut:

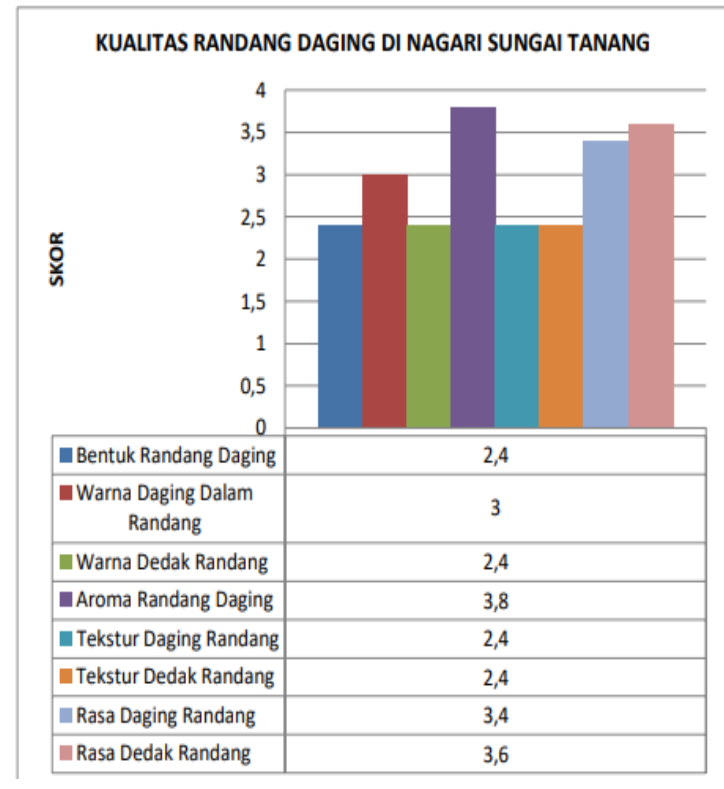

Grafik 1: Rata-rata kualitas randang daging Nagari Sungai Tanang

Dari grafik di atas dapat dilihat hasil rata-rata untuk kualitas bentuk (Persegi, rapi) yaitu 2,4 yang meyatakan kualitas bentuk potongan daging sapi yaitu kurang persegi rapi. Rata-rata penilaian warna daging dalam (Coklat Kehitaman) yaitu 3 yang menyatakan warna dalam daging randang cukup coklat kehitaman. Rata-rata penilaian warna dedak randang (Coklat Kehitaman) yaitu 2,4 yang menyatakan warna dedak randang kurang coklat kehitaman. Rata-rata penilaian aroma randang daging (harum kelapa dan bumbu) yaitu 3,8 yang menyatakan aroma randang daging harum kelapa dan bumbu. Rata-rata penilaian tekstur daging randang (empuk) yaitu 2,4 yang menyatakan tekstur daging randang kurang empuk. Rata-rata penilaian tekstur dedak randang daging (Kering berminyak) yaitu 2,4 yang menyatakan tekstur dedak randang daging kurang kering berminyak. Rata-rata penilaian rasa daging randang (meresap bumbu) yaitu 3,4 yang menyatakan rasa daging randang cukup meresap bumbu. Rata-rata penilaian rasa dedak randang (gurih) yaitu 3,6 yang menyatakan rasa dedak randang yaitu gurih.

Hasil penilaian organoleptik oleh 5 orang panelis terhadap kualitas randang daging dari resep standar Kabupaten Agam Nagari Tabek Panjang meliputi bentuk, warna, aroma, tekstur dan rasa dapat dilihat pada grafik berikut:

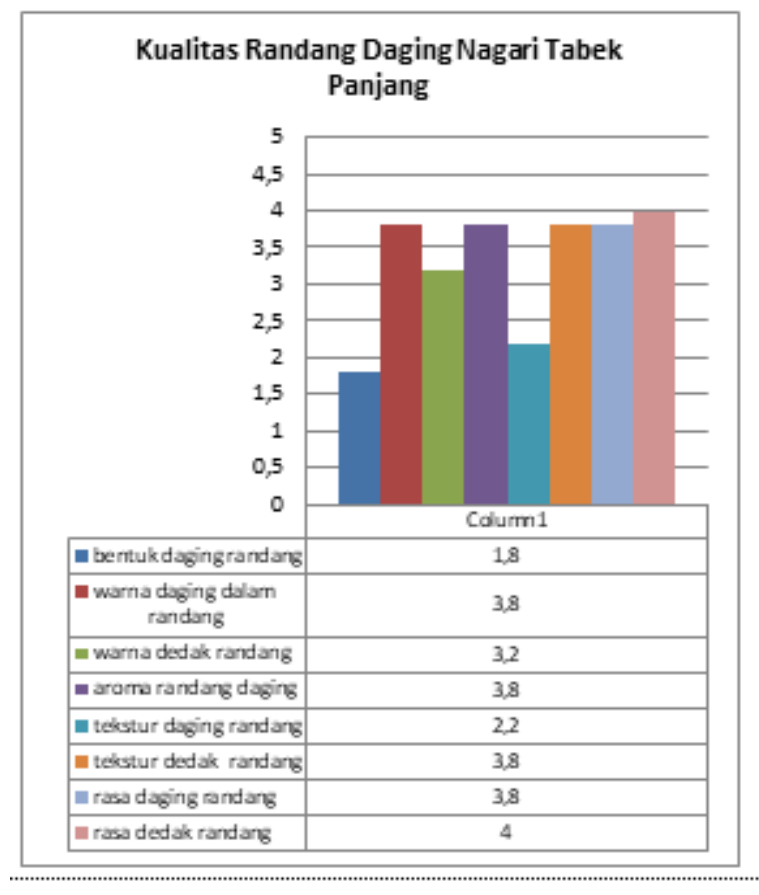

Grafik 2: Rata-rata kualitas randang daging Nagari Tabek Panjang

Dari grafik di atas dapat dilihat hasil rata-rata untuk kualitas bentuk (Persegi, rapi) yaitu 1,8 yang meyatakan kualitas bentuk potongan daging sapi yaitu kurang persegi rapi. Rata-rata penilaian warna daging dalam (Coklat Kehitaman) yaitu 3,8 yang menyatakan warna dalam daging randang coklat kehitaman. Rata-rata penilaian warna dedak randang (Coklat Kehitaman) yaitu 3,2 yang menyatakan warna dedak randang coklat kehitaman. Rata-rata 
penilaian aroma randang daging (harum kelapa dan bumbu) yaitu 3,8 yang menyatakan aroma randang daging harum kelapa dan bumbu. Rata-rata penilaian tekstur daging randang (empuk) yaitu 2,2 yang menyatakan tekstur daging randang kurang empuk. Rata-rata penilaian tekstur dedak randang daging (Kering berminyak) yaitu 3,8 yang menyatakan tekstur dedak randang daging kering berminyak. Rata-rata penilaian rasa daging randang (meresap bumbu) yaitu 3,8 yang menyatakan rasa daging randang meresap bumbu. Rata-rata penilaian rasa dedak randang (gurih) yaitu 4 yang menyatakan rasa dedak randang yaitu gurih.

Hasil penilaian organoleptik oleh 5 orang panelis terhadap kualitas randang daging dari resep standar Kabupaten Agam Nagari Baso meliputi bentuk, warna, aroma, tekstur dan rasa dapat dilihat pada grafik berikut:

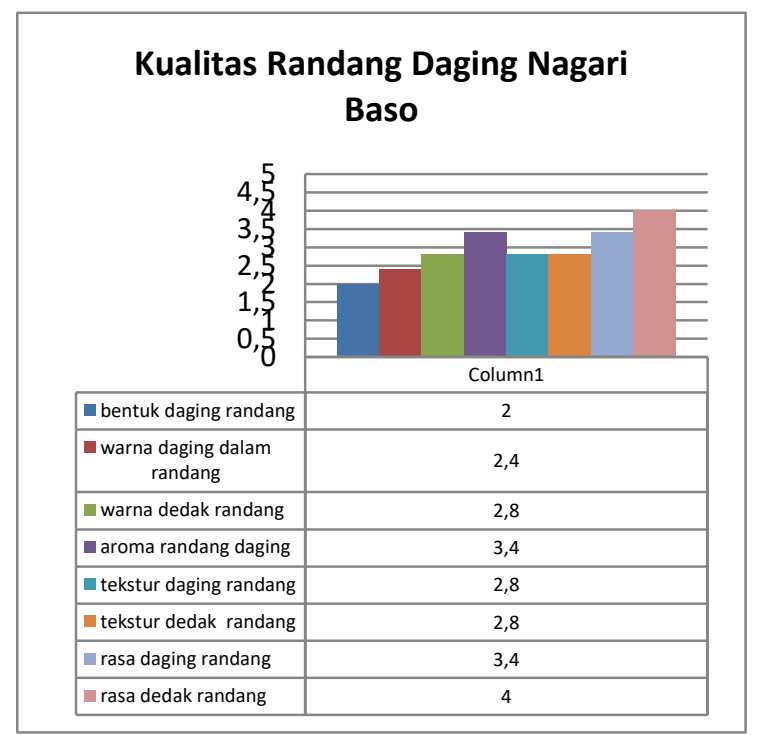

Grafik 3: Rata-rata kualitas randang daging Nagari Baso

Dari grafik di atas dapat dilihat hasil rata-rata untuk kualitas bentuk (Persegi, rapi) yaitu 2 yang meyatakan kualitas bentuk potongan daging sapi yaitu kurang persegi rapi. Rata-rata penilaian warna daging dalam (Coklat Kehitaman) yaitu 2,4 yang menyatakan warna dalam daging randang kurang coklat kehitaman. Rata-rata penilaian warna dedak randang (Coklat Kehitaman) yaitu 2,8 yang menyatakan warna dedak randang cukup coklat kehitaman. Rata-rata penilaian aroma randang daging (harum kelapa dan bumbu) yaitu 3,4 yang menyatakan aroma randang daging harum kelapa dan bumbu. Rata-rata penilaian tekstur daging randang (empuk) yaitu 2,8 yang menyatakan tekstur daging randang empuk. Rata-rata penilaian tekstur dedak randang daging (Kering berminyak) yaitu 2,8 yang menyatakan tekstur dedak randang daging kering berminyak. Rata-rata penilaian rasa daging randang (meresap bumbu) yaitu 3,4 yang menyatakan rasa daging randang meresap bumbu. Rata-rata penilaian rasa dedak randang (gurih) yaitu 4 yang menyatakan rasa dedak randang yaitu gurih.

Hasil penilaian organoleptik oleh 5 orang panelis terhadap kualitas randang daging dari resep standar Kabupaten Agam Nagari Koto Baru meliputi bentuk, warna, aroma, tekstur dan rasa dapat dilihat pada grafik berikut:

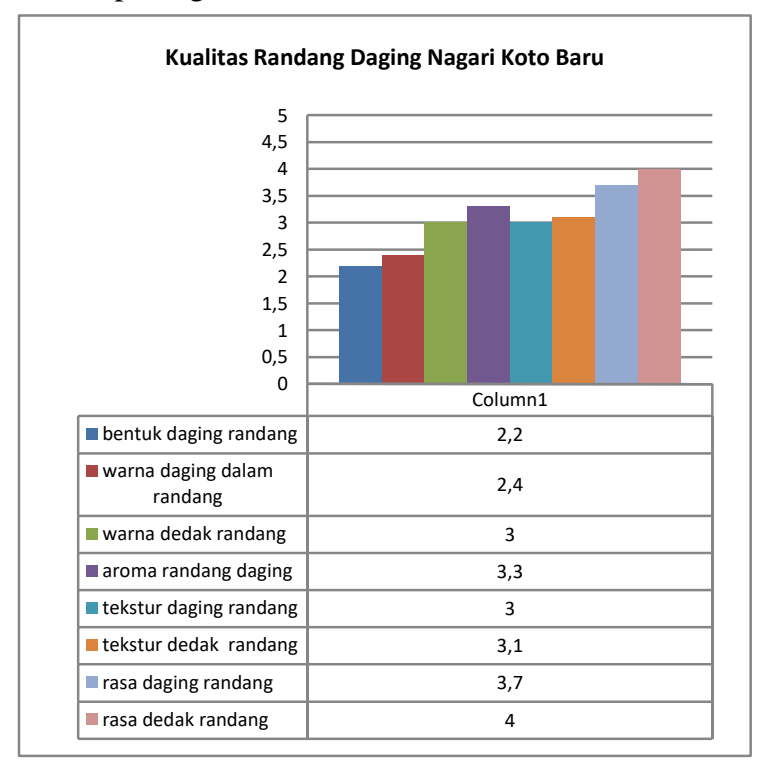

Grafik 4: Rata-rata kualitas randang daging Nagari Koto Baru

Dari grafik di atas dapat dilihat hasil rata-rata untuk kualitas bentuk (Persegi, rapi) yaitu 2,2 yang meyatakan kualitas bentuk potongan daging sapi yaitu kurang persegi rapi. Rata-rata penilaian warna daging dalam (Coklat Kehitaman) yaitu 2,4 yang menyatakan warna dalam daging randang kurang coklat kehitaman. Rata-rata penilaian warna dedak randang (Coklat Kehitaman) yaitu 3 yang menyatakan warna dedak randang cukup coklat kehitaman. Rata-rata penilaian aroma randang daging (harum kelapa dan bumbu) yaitu 3,3 yang menyatakan aroma randang daging harum kelapa dan bumbu. Rata-rata penilaian tekstur daging randang (empuk) yaitu 3 yang menyatakan tekstur daging randang cukup empuk. Rata-rata penilaian tekstur dedak randang daging (Kering berminyak) yaitu 3,1 yang menyatakan tekstur dedak randang daging kering berminyak. Rata-rata penilaian rasa daging randang (meresap bumbu) yaitu 3,7 yang menyatakan rasa daging randang meresap bumbu. Rata-rata penilaian rasa dedak randang (gurih) yaitu 4 yang menyatakan rasa dedak randang yaitu gurih. 


\section{Pembahasan}

Makanan yang memiliki kualitas yang baik dapat dilihat dari pengaruh yang ditimbulkannya, yaitu terjadinya rangsangan yang dapat dirasakan oleh alat indera perasa pada tubuh manusia, terutama pada indera penglihatan, indera penciuman dan indera pengecapan. Kualitas randang daging dapat dilihat dari segi bentuk, warna, aroma, tekstur dan rasa.

a. Bentuk

Bentuk merupakan tampilan secara keseluruhan dari makanan. Bentuk merupakan kriteria penampilan yang harus ada pada makanan. Bentuk makanan dapat dicetak atau sesuai dengan kreatifitas pembuatnya. Hariadi, dkk (2012:8) berpendapat bahwa, Satu Kg daging biasanya dipotong menjadi 40 bingkah. Bentuk potongan daging yang digunakan dalam pengolahan randang daging itu bervariasi, tergantung dimana tempat pengolahannya. Karena setiap daerah memiliki ciri khasnya masing-masing. Dari hasil uji organoleptik 4 resep standar randang daging Nagari Sungai Tanang, Tabek Panjang, Baso dan Koto Baru kualitas bentuk yang dihasilkan yaitu kurang persegi rapi.

b. Warna

Warna merupakan faktor utama yang diamati oleh konsumen. Menurut Winarno (2004:171), Suatu bahan yang bergizi, enak, dan teksturnya sangat baik, tidak akan dimakan apabila memiliki warna yang tidak sedap dipandang atau memberi kesan telah menyimpang dari warna yang seharusya. Warna randang daging yaitu coklat kehitaman yang dihasilkan dari proses memasak yang lama dari proses pengolah randang daging dan bahan yang digunakan dalam pembuatan randang. Dari hasil uji organoleptik 4 resep standar randang daging kualitas warna dalam yang dihasilkan yaitu bervariasi di setiap Nagarinya yaitu untuk Nagari Sungai Tanang cukup coklat kehitaman, Nagari Tabek Pajang Coklat Kehitaman, Nagari Baso dan Koto Baru yaitu kurang coklat kehitaman. Sedangkan untuk hasil warna dedak randang daging Nagari Sungai Tanang kualita yang dihasilkan yaitu cukup coklat kehitaman, dan untuk Nagari Tabek Panjang, Baso dan Koto Baru yaitu coklat kehitaman.

c. Aroma

Aroma yang dihasilkan dapat menambah tingkat penerimaan konsumen terhadap suatu produk. Makanan yang beraroma harum ditentukan oleh pemakaian bahan yang berkualitas. Hal ini diperkuat dengan pendapat Sutomo, (2012:6) Aroma randang sangat khas, legit dan sangat harum. Aroma randang daging yang diharapkan dari kualitas randang daging yaitu harum kelapa dan bumbu. Hasil organoleptik 4 resep standar randang daging kualitas aroma yang dihasilkan di Nagari Sungai Tanang dan Tabek Panjang yaitu harum kelapa dan bumbu, sedangkan untuk Nagari Baso dan Koto Baru yaitu cukup harum kelapa dan bumbu.

d. Tekstur

Tekstur adalah susunan yang dapat dirasakan melalui indera peraba baik jari maupun tangan. Tekstur yang diharapkan pada randang daging adalah pada bagian bumbu randang daging berminyak dan tekstur daging pada randang empuk karena proses pengolahan yang lama. Tekstur daging randang dari hasil organoleptik 4 resep standar randang daging untuk Nagari Sungai Tanang dan Tabek Panjang yaitu kurang empuk sedangkan untuk Nagari Baso dan Koto Baru yaitu cukup empuk. Hasil penilaian tekstur dedak randang daging untuk Nagari Sungai Tanang, Baso dan Koto Baru yaitu cukup kering berminyak, sedangkan Nagari Tabek Panjang kering berminyak.

e. Rasa

Rasa merupakan aspek terpenting dalam suatu cita rasa masakan. Menurut Wynda (2019:33), Rasa randang daging adalah gurih, karena sangat mudah diterima oleh semua lidah. Pada penelitian ini rasa yang diinginkan dari randang daging adalah rasa gurih. Dari hasil uji organoleptik 4 resep standar randang daging kualitas rasa daging randang yang dihasilkan yaitu bervariasi di setiap Nagarinya yaitu untuk Nagari Sungai Tanang dan Baso rasa daging randang yang dihasilkan yaitu bumbunya cukup meresap, untuk Nagari Tabek Panjang dan Koto Baru yaitu bumbu meresap. Penilaian kualitas rasa dedak randang daging untuk Nagari Sungai Tanang, Tabek Panjang, Baso dan Koto Baru yaitu menyatakan gurih.

\section{Kesimpulan}

Berdasarkan hasil penelitian dan pembahasan dapat ditarik kesimpulan bahwa kualitas randang daging yang ada di Kabupaten Agam Nagari Sungai Tanang, Tabek Panjang, Baso dan Koto Baru memiliki kualitas yang berbeda-beda diihat dari aspek (bentuk, warna, aroma, tekstur dan rasa).

\section{Daftar Pustaka}

1. Elida. 2014. Festival Rendang Padang 2012 dan Lomba Cipta Lagu Tentang Rendang

2. Hariadi. Ernatip. Silvia Devi. Rismadona. Reza Lahardo. Yulisman. Yoka Y. Agustinawarni. 
Kardil. Suriani. Nurman. 2012. Inventarisasi

Perlindungan Karya Budaya Randang Minangkabau. Padang: Bpsnt Padang Press.

3. Sutomo, B. (2012). Rendang: Juara Masakan Terlezat Sedunia. Kawan Pustaka

4. Winarno, F. G. (2008). Kimia Pangan Dan Gizi:

Edisi Terbaru. Jakarta. Gramedia Pustaka

Utama, 31

5. Wynda Dwi Amalia. 2019. Randang Bundo. Jakarta: Pt Gramedia Pustaka Utama 